\title{
Sır Baraj Gölet'inde Yaşayan Balık Örneklerinde Toplam Alfa ve Beta Radyoaktivite Seviyelerinin Ölçülmesi (Kahramanmaraş, Türkiye)
}

\author{
Hanifi ÇAM* \\ Kahramanmaraş Sütçü Imam Üniversitesi, Teknik Bilimler Meslek Yüksek Okulu, Elektronik ve Otomasyon \\ Bölümü, Kahramanmaraş, TÜRKIYYE \\ (ORCID: 0000-0002-9980-0037)
}

\begin{abstract}
$\ddot{\mathbf{O z}}$
Kahramanmaraş il sınırları içerisinde yer alan Sır Baraj Gölet'i, Ceyhan, Körsülü ve Aksu nehirleri ile beslenmektedir. Gölet, en fazla Aksu Çayı tarafından aşırı bir şekilde kirletilmektedir. Gölet'in farklı bölgelerinde kültür balıkçılığı yapılarak değişik türlerde balıklar yetiştirilmektedir. Bölgede yer yer balık ölümlerinin gerçekleşmesinden dolayı, göletin radyoaktif açıdan değerlendirilmesinin gerekli olduğu düşünülmüştür. Bu sebeple gölette yaşayan çeşitli balık türlerinden örnekler alındı. Bu örneklerin toplam alfa ve toplam beta radyoaktivite seviyeleri ölçüldü. Toplam alfa radyoaktivitesi en fazla Alabalık 'da görülürken en az Çupra 'da görüldü. Toplam beta radyoaktivitesi ise en fazla yine Alabalık 'da görülürken en az yayın balığında görüldü. Tespit edilen sonuçlar, değerlendirildiğinde radyoaktif olarak, insan sağlığ1 açısından bir sorun oluşturmadığ ancak balık ölümlerinin kimyasal kirlilikten kaynaklanmış olabileceği düşünülmektedir.
\end{abstract}

Anahtar kelimeler: Toplam Alfa, Toplam Beta, Balık, Radyoaktivite

\section{Measurement of Gross Alpha and Beta Radioactivity Levels in Fish Samples Living in Sır Dam Pond (Kahramanmaraş, Turkey)}

\begin{abstract}
Sır Dam Pond, located within the Kahramanmaras province borders, is fed by Ceyhan, Körsülü and Aksu rivers. Pond is heavily polluted, especially by Aksu Stream. In different parts of pond, different types of fish are grown by fish farming. It was thought that pond should be evaluated in terms of radioactivity due to the fact that there were some fish deaths in the region. For this reason, samples from various fish species living in the pond were taken. The gross alpha and gross beta radioactivity levels of these samples were measured. While total alpha radioactivity was seen mostly in Trout, it was least seen in Bream. While total beta radioactivity was mostly seen in Trout, it was least seen in catfish. When the detected results are evaluated, it is thought that radioactivity does not pose a problem in terms of human health, but fish deaths may have resulted from chemical pollution.
\end{abstract}

Keywords: Gross Alpha, Gross Beta, Fish, Radioactivity

\section{Giriş}

Nüfusun sürekli artışı ve sanayileşme sonucu, özellikle sularda ağır metal seviyelerinin yükselmesi ile ilgili birçok çalışma yapılmıştır. Ağır metaller jeolojik ve antropojik kaynaklardan sürekli artarak sulara karışmaktadır. Ağır metaller, eser seviyede bulunsa dahi suda yaşayan canlıların bünyelerinde birikerek zehir etkisi yapabilmektedir [1-4]. Balık, gibi sucul organizmalar bulundukları ortamlardan önemli miktarda kirleticileri bünyelerinde biriktirdiğinden dolayı, sucul ortamların kirliliği ve izlenmesi çalışmalarında yoğun bir şekilde ve sürekli olarak kullanılmaktadır [5-7]. Genellikle, balık ve diğer sucul organizmalarda ăgır metal birikimleri dokulara göre farklılıklar göstermektedir. Örneğin, balıkların karaciğer dokuları, solungaç ve kas dokuya kıyasla daha yüksek birikimler göstermektedir [8-

*Sorumlu yazar: hanifi70@gmail.com

Geliş Tarihi: 22.03.2021, Kabul Tarihi: 13.07.2021 
10]. Ayrıca, balıkların eser seviyede metal kirlenmesi ve insanların tüketimindeki artış miktarı, potansiyel risklerin tahmininde, tatlı su sistemlerinin belirgin özelliklerinden birisidir [11-13]. Ağır metallerin alınması, solungaç, besin yolu ve deri aracılığı ile olmaktadır. Alınan bu ağır metaller, taşıyıcı proteinlere bağlanarak kan yolu ile dokulara ve oradan da organlara taşınmaktadır. Böylece burada yüksek konsantrasyonlara ulaşmaktadır [14,15]. Ayrıca ağır metal birikimlerinin, balıkların doku ve organlarındaki artışı, farklı kan ve enzim değerleri, büyüme ve gelişmeyi etkilediği belirtilmiştir [16].

$\mathrm{Su}$ ve atık sudaki radyoaktif kirlilik, doğal veya insanlar tarafindan oluşturulan yapay kaynaklardan meydana gelmektedir. Fabrika ve şehir atıkları, nükleer yakıtların kullanılması, radyoizotopların tıpta ve endüstride kullanılması ve nükleer silahların denenmesinden kaynaklanan atmosferdeki radyoaktif atıklar ve ayrıca radyoaktif çekirdeklerden meydana gelen kirlilik, elemental ve radyoaktif kirliliğe neden olmaktadır [17,18].

Yeryüzü kaynaklı olan doğal radyoaktivite, dünyanın oluşumundan bu yana bütün canlıları etkilemektedir. Doğal radyoaktifliğin neden olduğu doğal radyasyon, uzaydan gelen kozmik 1şınlar, kaya, toprak, su ve hava içerisindeki doğal olarak oluşmuş radyo çekirdeklerin bozunmaları sonucu yayılan ışınlardan oluşmaktadır. Doğal radyoaktif elementler, dünyanın hemen hemen her yerinde bulunmaktadır [19].

Doğal radyasyonların temel seviyeleri, bölgenin jeolojik ve coğrafik yapısına bağlı olarak da değişiklik göstermektedir [20]. Toprak ve kayaların mineralojik yapıları ile coğrafi yükseklik, bölgenin temel radyasyon seviyesini etkilemektedir. Bir bölgenin veya bir yerin doğal temel seviye radyasyonunun belirlenmesi, onun radyolojik açıdan incelenmesi ve toprağında, suyunda ve havasında bulunan doğal radyoaktivitenin belirlenmesi gerekir.

Radyoaktif kirlenmenin büyüklüğünü tespit etmek için alfa ya da beta yayan radyoizotopların tayinleri, birçok radyo kimyasal ayırma ve saflaştırma işlemleri yapmak gerektiğinden dolayı, her bir radyoizotopun tayini oldukça zaman alıcı ve pahalıdır. Bu yüzden radyoaktif kirliliğin tespitinde öncelikli olarak toplam alfa ve toplam beta radyoaktivite seviyelerinin tespit edilmesi ve limit değerlerin üzerinde bir aktivite ölçülmesi ile radyoaktif kirlilikten söz edebiliriz.

Sır Baraj Gölet'i, sanayi, kanalizasyon ve evsel atıklar ile sürekli kirletilmektedir. Gölette yer yer balık ölümlerinin gerçekleşmesinden dolayı göletin, radyoaktif açıdan değerlendirilmesi gerektiği düşünülmüştür.

\section{Materyal ve Metot}

Araştırma sahası olan Kahramanmaraş ili Sır Baraj Gölü, Kahramanmaraş ilinin Güney-Batı'sında 45 $\mathrm{km}$. mesafede ve $12.950 \mathrm{~km}^{2}$ lik bir havzaya sahiptir. Ceyhan Nehri üzerinde kurulan bu baraj gölü, normal su kotunda $47,5 \mathrm{~km}^{2}$ lik bir alana sahiptir. Ayrıca girintili ve çıkıntılı bir görünüm arz etmekte olup baraj kıyıları az engebeli ve düzlük alanlardan oluşmaktadır [21]. Gölet'i besleyen ana su kaynakları Ceyhan, Körsülü ve Aksu nehirleridir. Baraj Gölet'inin çevresinde 7 kasaba ve bunlara bağl1 20 köy bulunmaktadır. Gölet kenarına yakın olan Afşar, Cüceli, Kızıldamlar ve Kızılseki köylerinde tarım ve hayvancılığın yanı sıra balıkçılık da yapılmaktadır. Ayrıca Gölette kültür balıkçılığı da yapılmakta olup Dünya'nın birçok ülkesine çeşitli türlerde balık ihracatı yapılmaktadır.

Sır Baraj Gölet'ini kirleten başlıca faktörler; Kahramanmaraş ilinin kanalizasyon ve çöplügünün yanı sıra özellikle sanayi atıklarının Aksu Çayı'na karışması ve buradan da Sır Baraj Göleti'ne karışmasıyla gerçekleşmektedir. Sularının büyük bir kısmını karstik kaynaklardan alan Aksu Çayı, yaklaşık $1.740 \mathrm{~km}^{2}$ ' lik bir sahanın sularını drene ettikten sonra Kahramanmaraş Ova'sında Sır Baraj Göleti'ne dökülmektedir [22,23]. Ayrıca şehirdeki fabrikaların çoğunda arıtma sisteminin olmaması veya olanların da maliyeti arttırdığı gerekçesiyle çalıştırılmaması çalışmanın önemini daha da arttırmaktadır. Araştırma sahasının genel bir görünümü Şekil 1'de verilmektedir.

Ayrıca Şekil 2 ve 3'de Aksu Nehrinin Sır Baraj Gölet'ine dökülmeden önceki ve sonraki durumu görülmektedir. 


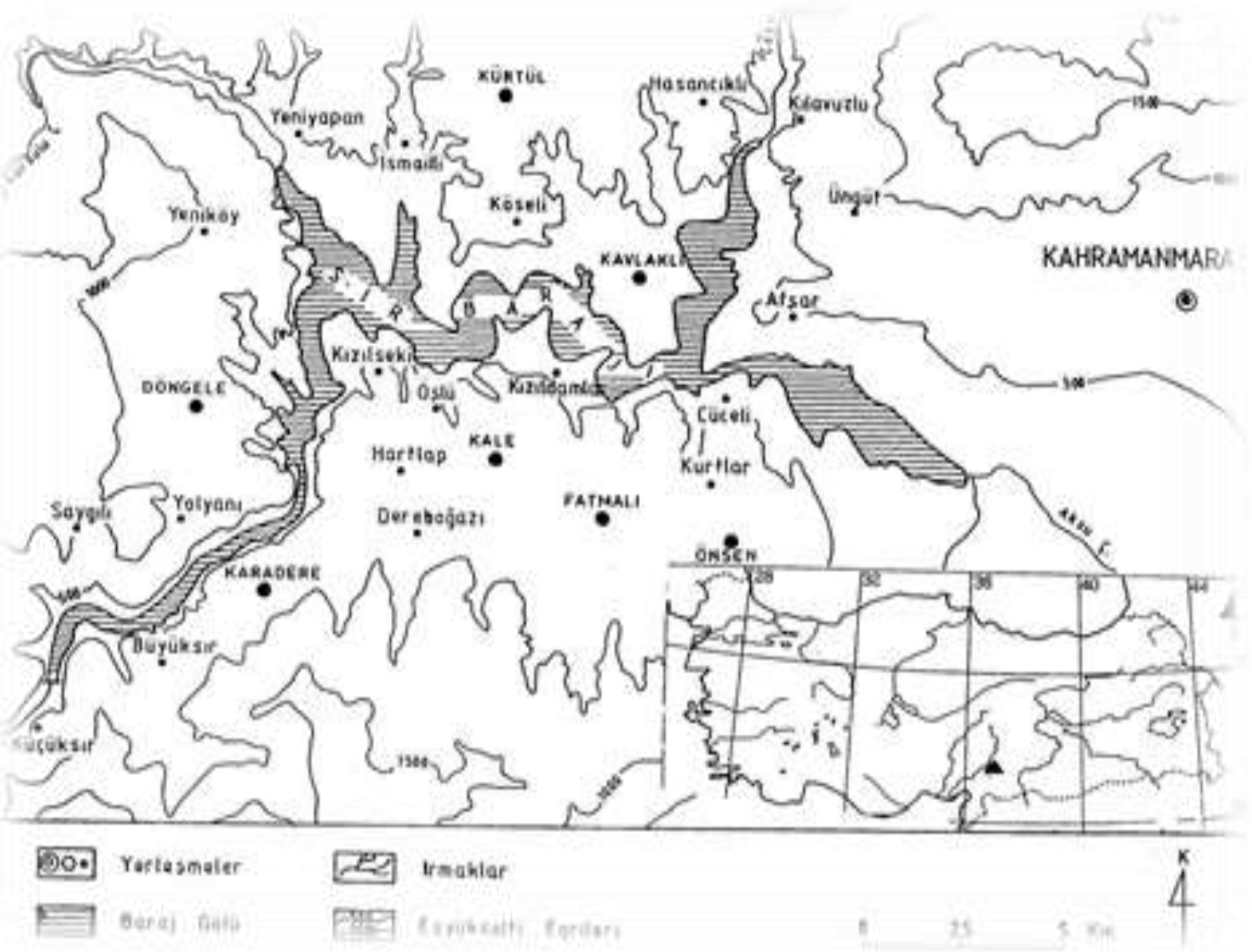

Şekil 1. Sir Baraj Gölet'inin genel görünümü [24].

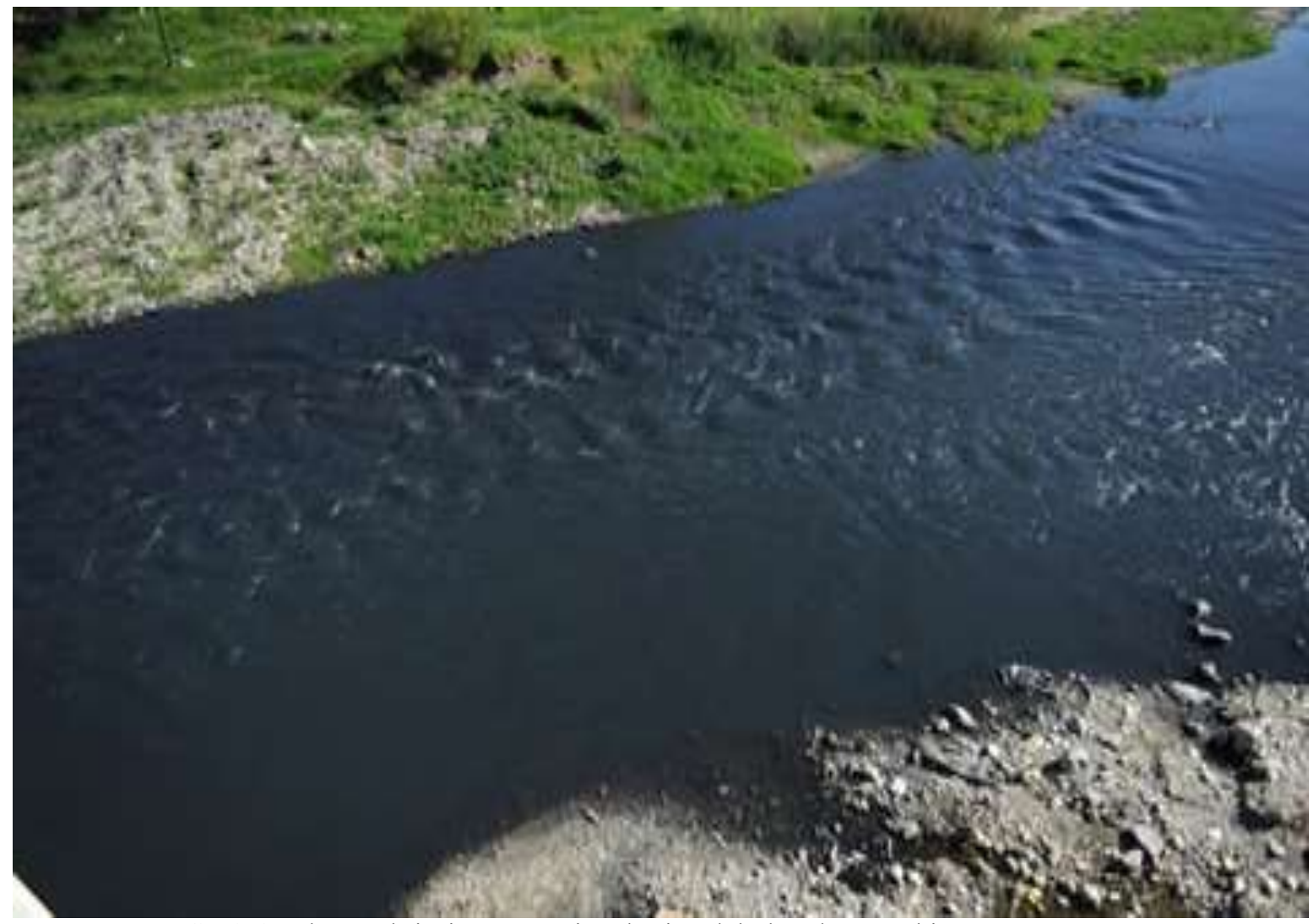

Şekil 2. Aksu Nehri'nin Sır Baraj Gölet'ine dökülmeden önceki durumu $[25,26]$. 


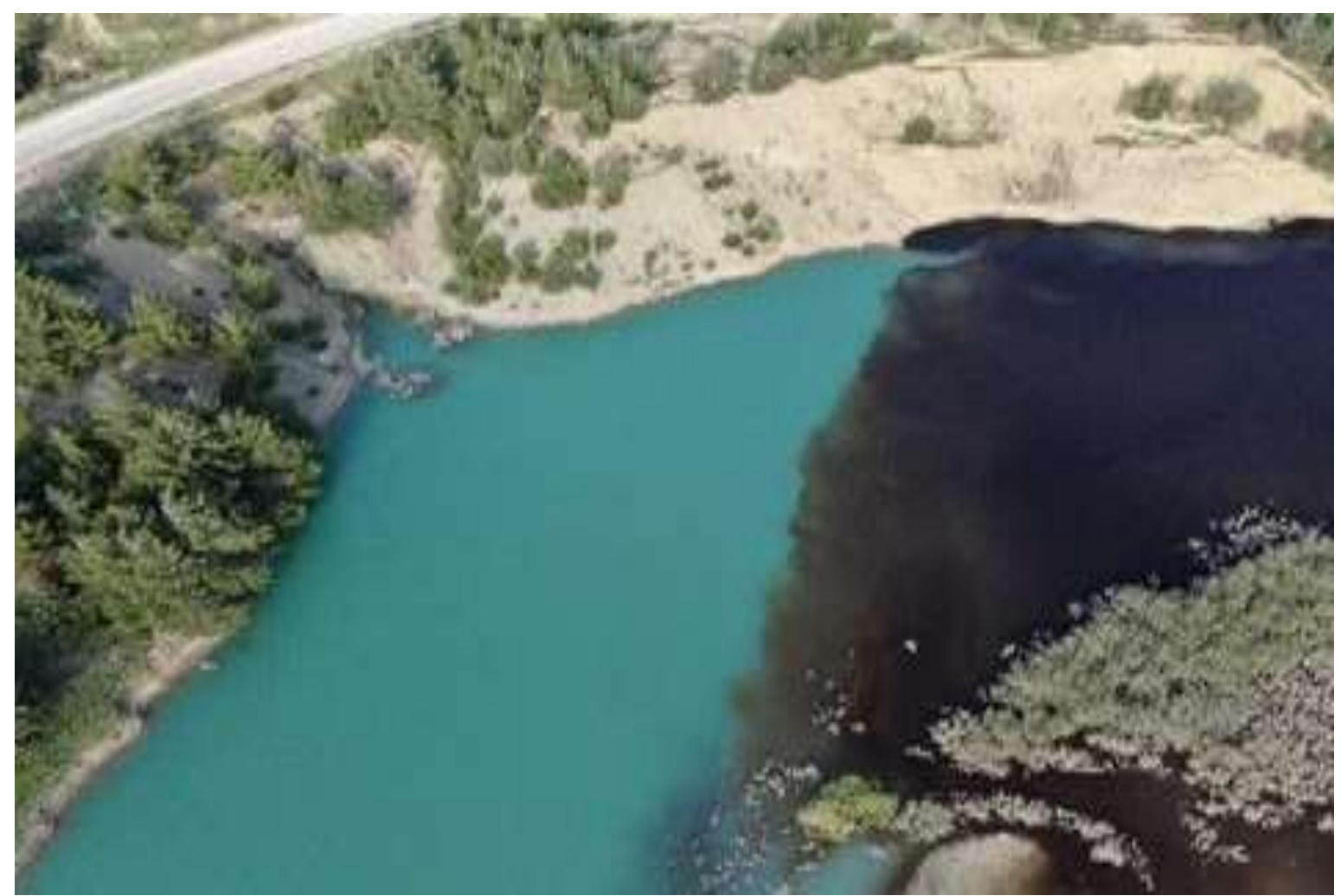

Şekil 3. Aksu Nehri'nin Sır Baraj Gölet'ine döküldükten sonraki durumu [25,26].

Sır Baraj Gölet'inin tabanı, Ceyhan Nehri ve Aksu Çayı'nın taşıdıkları alüvyonların birikmesiyle oluşmaktadır. Araştırma havzasını oluşturan alüvyon toprakların materyalini değişik yaştaki formasyonlar oluşturmaktadır. Bu formasyonların en yaygın olanı kalkerler olduğundan alüvyon topraklar kireçlidir. Araştırma sahasının geniş bir kısmını kahverengi orman toprakları çevrelemektedir. Toprak profilinde ise kahverengi hâkimdir.

Çalışma sahamız olan Sır Baraj Gölet'i ise bu jeolojik birimlerden olan Post Alpin Formasyonu hâkimdir. Post Alpin Formasyonları; Miosen, Pliosen ve Kuaterner birimleri ile ifade edilmektedir. Çalışma istasyonlarımızın geniş bir alanını kapsayan şelmo formasyonu, Sır Baraj Gölet'i çevresinde geniş bir şekilde mostra vermektedir. Karasal kırıntılardan oluşan ve egemen litolojisi konglomera olan birim, tabanda sarımsı yeşil renkli kil taşı, silttaşı düzeyi ile başlar. Üste doğru kırmızı renkli çamur taşı, silttaşı, grimsi yeşilimsi, yer yer kırmızımsı silttaşı-kumtaşı ve olgun polijenik elemanlı konglomerakumtaşı ardalanması ile devam etmektedir.

Çalışma sahamızın Aksu Çayı'nın Baraj Gölet'ine katıldığı bölge ise Besni Formasyonu olarak adlandırılmaktadır. Formasyon genellikle 1-2 m kalınlıkta, açık gri, yeşilimsi renkli, taneleri boylanmalı, düzensiz tabakalamalı, peridotit çakıllı, karbonat çimentolu konglomeralar ile başlar ve üste doğru konglomeraların boyları incelerek kırıntıl1, açık kırmızımsı, sarımsı renkli kalkerlere geçmektedir. En üst bölümde ise kırmızı ve pembe renkli, köşeli kırıntılardan oluşan kumtaşı ile son bulmaktadır [22].

\section{1. Örneklerin toplanması}

Sır Baraj Gölet'inin kirlenmesine sebep olan Aksu Nehri'nin, gölete dökülmeden önceki ve döküldükten sonraki durumu, özellikle Alabalık başta olmak üzere çeşitli türlerde kültür balıkçıllı̆ının yapılmış olduğu bölgeler ve balık ölümlerinin gerçekleştiği yerler ile göletin toprak ve kayaç yapısıda dikkate alınarak Şekil 4' de gösterildiği gibi istasyonlar belirlenmiştir. Belirlenen bu yerlerden balık örnekleri, üretim kafeslerinden ve bölgedeki diğer balıkçılardan temin edilerek buz korumalı kaplar içerisinde laboratuvar ortamına getirilmiştir. 


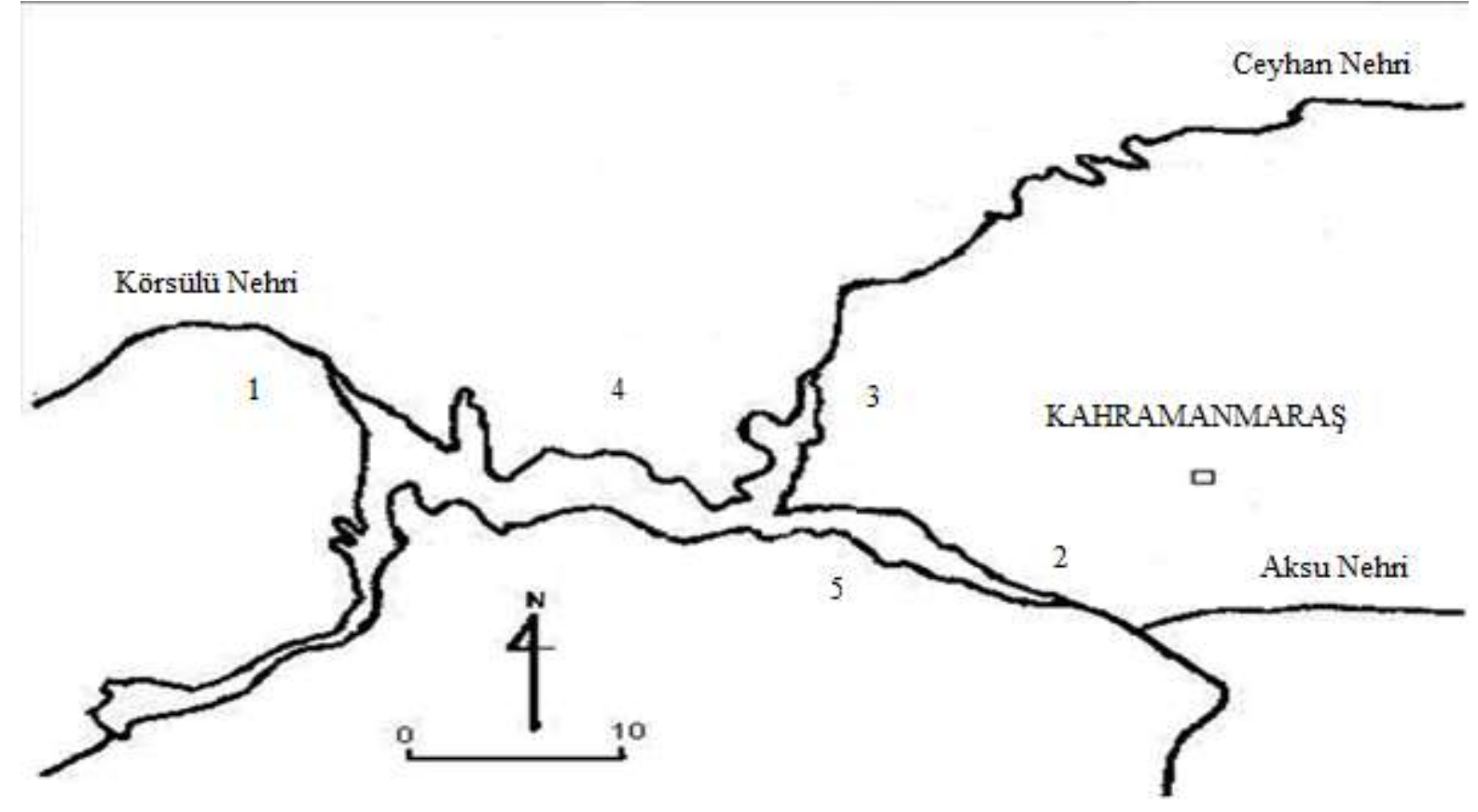

Şekil 4. Sir baraj Gölet'inde belirlenen istasyonlar [21].

\section{2. Örneklerin sayıma hazır hale getirilmesi}

Laboratuvar ortamına getirilen balık örnekleri bir takım ön işlemlerden geçirildikten sonra alüminyum folyolar içerisine sarılarak $105{ }^{\circ} \mathrm{C}$ 'de etüv fırınında 7 gün boyunca kurutma işlemine tabi tutulmuştur. Balıkların yağ oranı yüksek olduğunda geç kurumuştur. Kurutma işlemi esnasında buharlaşma ile kaybolacak radyoaktivite miktarı ihmal edilebilecek düzeylerde olduğu için hesaplamalara katılmamıştır. Ayrıca balık ölümlerinin gerçekleştiği Aksu bölgesinde bol miktarda bulunan, sazan balığının karaciğer ve derisine $105{ }^{\circ} \mathrm{C}$ 'de etüv fırınında 3 gün boyunca kurutma işlemi uygulanmıştır. Bu süreç sonucunda tamamen kuruması sağlanan örnekler, havanda dövülerek toz haline getirilmiştir. Daha sonra örnekler 100 mesh gözenekli özel bir elek kullanılarak elenmiş ve tek kullanımlık temiz plastik poşetler içerisinde etiketlenmiştir. Sonra bu örnekler toplam alfa sayımı için büyük planşet içerisine $25 \mathrm{mg}$ ve toplam beta sayımı için küçük planşet içerisine $10 \mathrm{mg}$ numune homojen bir dağılım sağlayacak şekilde dağıtılmıştır. Yukarıda bahsedilen süreçler sonucunda sayıma hazır hale getirilen örnekler, uygun detektör sistemleri kullanılarak toplam alfa ve toplam beta radyoaktivite seviyeleri ölçülmüştür.

\subsection{Kullanılan sayım sistemleri ve sayaçlar}

$\mathrm{Bu}$ çalışmada; örneklerin toplam alfa radyoaktivite ölçümleri için 7286 düşük seviyeli alfa sayıcısı, toplam beta radyoaktivite ölçümleri için ise penceresiz sintilasyon sayacı ve BP4 beta proplu sintilasyon sayacı kullanılmıştır.

7286 düşük seviyeli alfa sayıcısı; $44 \mathrm{~mm}$ çapında $\mathrm{ZnS}$ katmanlı katı bir inorganik sintilatör ile EMI 6097B tür bir foto çoğaltıcı tüp ve sayıcıdan oluşmaktadır. Sayıcı kısmına 4 adet birbirinden bağımsız foto çoğaltıcı tüp bağlanabilmektedir. Her bir foto çoğaltıcı tüp kendine ait ayarlanabilir yüksek voltaj kaynağına ve diskriminatör devresine sahiptir. Bu sistem esas olarak çok zayıf temel radyasyon ölçümlerinde ve düşük sayım hızlı uygulamalarda kullanılmak üzere tasarlanmıştır. Sistemin kalibrasyonu kullanma kılavuzu temel alınarak yapıldıktan sonra, örneklerin toplam alfa radyoaktivite ölçümleri için kalibrasyon faktörü kullanılmıştır [27].

Penceresiz sintilasyon sayacı; sintilatör ve bir foto çoğaltıcı tüpten ibarettir. Penceresiz sintilasyon sayacı katı örneklerden zayıf enerjili beta radyasyonu ya da alfa radyasyonu ölçümleri için 
düzenlenmiştir. Bu sintilasyon sayacının penceresiz olması ve sintilatör ile örnek arasındaki mesafenin 1,6 mm'den daha küçük olması sayım veriminin yüksek olmasını sağlamaktadır. Sistemin kalibrasyonu kullanma kılavuzu temel alınarak yapıldıktan sonra örneklerin toplam beta radyoaktivite ölçümleri için kalibrasyon faktörü kullanılmıştır [28].

BP4 beta proplu sintilasyon sayıc1; BP4 tipi bir sintilatör ve foto çoğaltıcı tüpten ibarettir. Sintilatör ve foto çoğaltıcı tüp, minimum 3,2 cm kalınlıkla \%4 oranında antimon içeren kurşun bir blok içerisine yerleştirilmiştir. Bu donanım zayıf enerjili beta radyasyonu ölçümleri için düzenlenmiştir [29].

\section{4. Örneklerin aktivite konsantrasyonlarının hesaplanması}

Örneklerin toplam alfa ve toplam beta aktivite konsantrasyonları aşağıdaki denklem kullanılarak hesaplanmıştır.

$\mathrm{A}_{\alpha}=[(\mathrm{NS} \pm \mathrm{SS}) \mathrm{xDF}] / 2,22$

$\mathrm{A}_{\beta}=[(\mathrm{NS} \pm \mathrm{SS})] / 2,22 \times \mathrm{D}$

bu denklemde; $\mathrm{A}_{\alpha}$ ve $\mathrm{A}_{\beta} \mathrm{pCi}$ cinsinden aktivite, NS ve SS sırası ile örneğin dakikadaki net sayım sayıs1 ve standart sapması (cpm), VDF verim düzeltme faktörüdür $(\mathrm{dpm} / \mathrm{cpm}), 2,22$ dönüşüm faktörü (1 pCi $=2,22 \mathrm{dpm})$, D ilgili kalibrasyon eğrisinden hesaplanan beta verim faktörü (cpm/dpm)'dür [30-33].

\section{Bulgular ve Tartışma}

\subsection{Sır Baraj Gölet'inde Üretilen ve Doğal Olarak Yetişen Balık Türlerinde Toplam Alfa ve Beta Radyoaktivite Seviyeleri}

Kahramanmaraş, Sır Baraj Gölet'inde doğal olarak ve üretim yoluyla yapılan çeşitli balık türlerinde toplam alfa ve beta radyoaktivite seviyeleri Tablo 1 ve Şekil 5'de verilmiştir.

Tablo 1. Sır Baraj Gölet'inde üretilen ve doğal olarak yetişen balık türlerinde toplam alfa ve beta radyoaktivite seviyeleri

\begin{tabular}{clcc}
$\begin{array}{c}\text { Örnek } \\
\text { No }\end{array}$ & \multicolumn{1}{c}{$\begin{array}{c}\text { Örnek Alınan Bölge ve } \\
\text { Balık Türü }\end{array}$} & $\begin{array}{c}\text { Toplam Alfa Radyoaktivitesi } \\
(\mathrm{Bq} / \mathrm{Kg})\end{array}$ & $\begin{array}{c}\text { Toplam Beta } \\
\text { Radyoaktivitesi }(\mathrm{Bq} / \mathrm{Kg})\end{array}$ \\
\hline 1 & Alabalık (Kızılseki) & $238.6 \pm 33$ & $121.6 \pm 30$ \\
2 & Sarı Balık (Kızılseki) & $42.4 \pm 30.5$ & $243.8 \pm 25.2$ \\
3 & Sazan Balı̆̆ (et, Aksu) & $124 \pm 33.5$ & $469 \pm 29$ \\
4 & Sazan Balı̆̆ (Deri, Aksu) & DLA & $558.5 \pm 24.3$ \\
5 & Sazan Balığ (Ciğer, Aksu) & $79 \pm 36.3$ & $669.6 \pm 36.4$ \\
6 & Alabalık (Hasancıklı) & $222.9 \pm 41.9$ & $921.5 \pm 45.7$ \\
7 & Yayın Balı̆̆1, (Kavlaklı) & $187.7 \pm 33.4$ & $57.1 \pm 33.1$ \\
8 & Çupra (Cüceli) & $61 \pm 32.7$ & $276.5 \pm 28$. \\
\hline
\end{tabular}

Tablo 1'den, toplam alfa radyoaktivitesi en düşük $42.4 \pm 30.5 \mathrm{Bg} / \mathrm{Kg}$ lık bir değer ile Kızılseki bölgesinde doğal olarak yetişen Sarı balık örneğinde görülürken en yüksek ise $238.6 \pm 33 \mathrm{Bg} / \mathrm{Kg}$ bir değer ile yine Kızılseki bölgesinde Alabalık örneğinde görülmüştür. Bu balık suni olarak yetiştirilerek yurt içi ve yurt dişına ihraç edilmektedir. Toplam beta radyoaktivitesi ise, en düşük Kavlaklı bölgesinde doğal olarak beslenen Yayın(et) balığı örneğinde $57.1 \pm 33.1 \mathrm{Bg} / \mathrm{Kg}$ olarak hesaplanırken en yüksek ise Hasancıklı bölgesinde, suni olarak yetiştirilen alabalık örneğinde $921.5 \pm 45.7 \mathrm{~Bq} / \mathrm{Kg}$ olarak hesaplanmıştır.

Hasancıklı bölgesinde üretilen Alabalıklarda toplam beta radyoaktivite seviyesinin yüksek oluşu dikkat çekicidir. Bunun nedeni, kullanılan yemlerden kaynaklanabileceği gibi bölgenin toprak ve kayaç yapısından da kaynaklanabilir. Alabalık üretim tesislerinin, Ceyhan nehrinin Sır Baraj Gölet'ine döküldüğü bölgede olması, nehrin gölete taş, toprak vb. partiküllerle birlikte taşımış olduğu radyoaktif parçacıkların etkisi de olabilir. Aksu bölgesinde doğal olarak yetişen Sazan balığının, etinde, toplam beta radyoaktivite seviyesinin $469 \pm 29 \mathrm{~Bq} / \mathrm{Kg}$, derisinde $558.5 \pm 24.3 \mathrm{~Bq} / \mathrm{Kg}$ ve ciğerlerinde 
$669.6 \pm 36.4 \mathrm{~Bq} / \mathrm{Kg}$ olması kayda değerdir. Toplam beta radyoaktivite seviyesinin balı̆̆ın ciğerlerinde yüksek çıkmasının sebebi toksik maddelerin ciğerlerde birikmesinden kaynaklanmış olabilir. Doğal sularda WHO'nun tavsiye ettiği toplam alfa radyoaktivitesinin üst sınır değeri $0,5 \mathrm{~Bq} / \mathrm{L}$ iken toplam beta radyoaktivitesinin üst sınır değeri ise $1 \mathrm{~Bq} / \mathrm{Ldir}[34]$. Ancak balık çeşitleri ile ilgili toplam alfa ve beta radyoaktivitesi için WHO'nun belirlediği herhangi bir sınır değer olmayıp balıklarda toplam beta radyoaktivitesinin yüksek çıkmasının nedeni, beta yayıcılarının alfa yayıcılardan fazla olmasından kaynaklanmış olabilir. Baraj göletinde toplam alfa ve toplam beta radyoaktivitesinin yükselmesine $238 \mathrm{U}$ ve $232 \mathrm{Th}$ ve $40 \mathrm{~K}$ radyonüklid izotoplarının katkı sağlamış olabileceği düşünülmektedir.

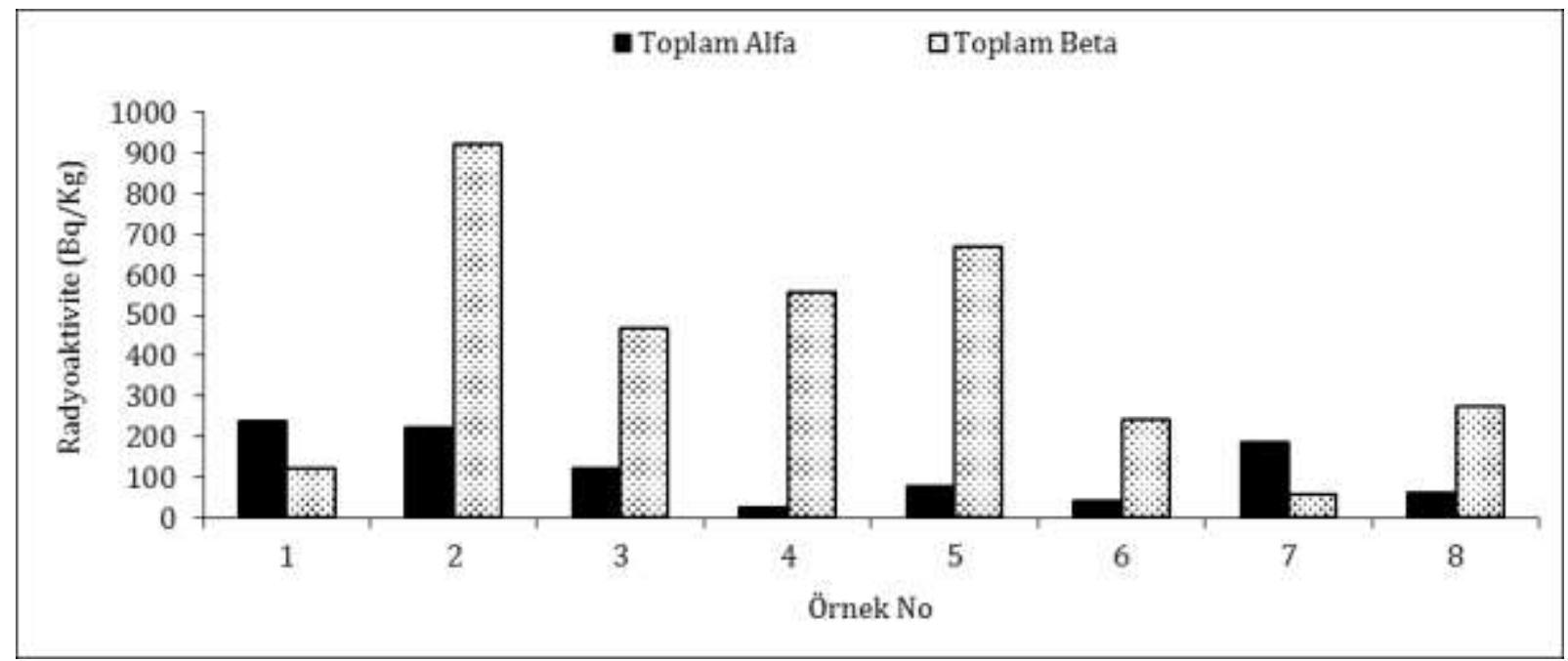

Şekil 5. Sır Baraj Göleti'nde üretilen ve doğal olarak yetişen balık türlerinde toplam alfa ve beta radyoaktivite seviyeleri

\section{Sonuç ve Öneriler}

Bu çalışmada Kahramanmaraş ili, Sır Baraj Gölet'i ve göleti besleyen Aksu nehrinin gölete döküldüğü yerde belirlenen istasyonlardan alınan balık örneklerinde toplam alfa ve beta radyoaktivite seviyeleri belirlenerek değerlendirildi. Sonuçların yapılan benzer çalışmalar ile uyum içinde olduğu görüldü [21].

Çalışma alanı olarak Sır Baraj Gölet'inin seçilme sebebi ise, gölette yer yer balık ölümlerinin gerçekleşmesi ve bölgenin jeolojik yapısının yanında özellikle göleti besleyen kollardan biri olan Aksu nehri ile baraj göletinin hızlı bir şekilde kirletilmesidir. Ayrıca yine fabrikaların kimyasal atıkları, yine baraj göletinin kirlenmesine sebep olmaktadır.

Bölgenin hâkim olan litolojisi, konglomera olan birim, tabanda sarımsı yeşil renkli kil taşı ve silttaşı seviyesi ile başlayıp, Üste doğru kırmızı renkli çamur taşı, silttaşı, kumtaşı ve olgun polijenik elemanlı konglomera-kumtaşı ardalanması ile devam etmektedir. Daha yukarılara doğru çıkıldıkça bazaltlar oluşmaktadır [4]. Göletin Aksu ve Cüceli istasyonlarında kısmen kil taşı, silttaşı, çamur taşı, kumtaş1 ve bazaltlardan oluştuğundan göletin doğal radyoaktivitesine bir katk1 yaptığı düşünülebilir. Özellikle kumtaşının içerisinde Uranyum grubunun yoğunlaşma eğiliminde olduğu bilinmektedir [35].

İlerde bu bölge üzerinde yapılacak olan çalışmalarda, insan, bitki ve hayvan sağlığ için hayati önem taşıyan radyoaktivite çalışmalarının derinleştirilerek insan ve hayvanlardan alınacak doku ve kan örnekleri ile maruz kaldıkları radyasyon dozları belirlenmelidir. Bölgede daha detaylı ve süreklilik arz eden bir radyoaktivite taramasının yapılması ve radyasyonun oluşturabileceği tehlikelere karşı tedbirlerin geliştirilmesi canlıların daha az radyasyon dozuna maruz kalmaları bakımından faydalı olacaktır. Ayrıca fabrikaların arıtma tesislerini kurarak çalıştırması ve şehrin çöplügünün uygun bir yere taşınmasının baraj göletinin radyoaktivite seviyesinin daha alt seviyelere inmesi bakımından faydalı olacağı düşünülmektedir. Bu çalışmanın sonuçları, gelecekte bu bölgede yapılacak çalışmalar için referans olarak kullanılabilir.

\section{Yazarların Katkısı}

Bu çalışmada tüm katkı yazara aittir. 


\section{Çıkar Çatışması Beyanı}

Bu çalışmada yazarlar arasında herhangi bir çıkar çatışması bulunmamaktadır.

\section{Araştırma ve Yayın Etiği Beyanı}

Yapılan çalışmada araştırma ve yayın etiğine uyulmuştur.

\section{Kaynaklar}

[1] Karadede, H. ve Ünlü, E. 2000. Concentrations of some heavy metals in water, sediment and fish species from the Atatürk Dam Lake (Euphrates), Turkey. Chemosphere, 41 (9): 1371-1376.

[2] Wagner, A., and Boman, J. 2003. Biomonitoring of trace elements in muscle and liver tissue of freshwater fish. Spectrochimica Acta Part B: Atomic Spectroscopy, 58 (12): 2215-2226.

[3] Eisler, R. 1988. Lead Hazards to fish, wildlife, and invertebrates: a synoptic review. Biological Report 85. Laurel, Maryland: US Fish and Wildlife Service.

[4] Nimmo, D. R., Willox, M. J., Lafrancois, T. D., Chapman, P. L., Brinkman, S. F., and Greene, J. C. 1998. Effects of metal mining and milling on boundary waters of Yellowstone National Park, USA. Environmental management, 22 (6): 913-926.

[5] Türkmen, A., Tepe, Y. ve Türkmen, M. 2008. Metal levels in tissues of the European Anchovy, Engraulis encrasicolus L., 1758, and Picarel, Spicara smaris L., 1758, from Black, Marmara and Aegean seas. Bulletin Environmental Contamination and Toxicology, 80: 521-525.5

[6] Türkmen, A., Tepe, Y., Türkmen, M. ve Mutlu, E. 2009. Heavy metal contaminants in tissues of the Garfish, Belone belone L., 1761, and the Bluefish, Pomatomus saltatrix L., 1766, from Turkey waters. Bulletin Environmental Contamination and Toxicology, 82: 70-74.

[7] Türkmen, A., Tepe, Y., Türkmen, M., ve Ateş, A. 2012. Investigation of Metals in Tissues of Fish Species from Akyatan Lagoon. Fresenius Environmental Bulletin, 21 (11c): 3562-3567.

[8] Tuzen, M. 2009. Toxic and essential trace elemental contents in fish species from the Black Sea, Turkey. Food and Chemical Toxicology, 47: 1785-1790.

[9] Carneiro, C.D., Marsico, E.T., de Jesus, E.F.O., Ribeiro, R.D.R. ve Barbosa, R.D. 2011. Trace elements in fish and oysters from Sepetiba Bay (Rio de Janeiro-Brazil) determined by total reflection X-ray fluorescence using synchrotron radiation. Chemical Ecology, 27: 1-8.

[10] Kandemir, S., Doğru, M.İ., Örün, İ., Doğru, A., Altaş. L., Erdoğan, K., Örün, G. ve Polat, N. 2010. Determination of Heavy Metal Levels, Oxidative Status, Biochemical and Hematological Parameters in Cyprinus carpio L., 1758 from Bafra (Samsun) Fish Lakes. Journal of Animal and Veterinary Advances, 9: 617-622.

[11] Allen-Gil, S. M., and Martynov, V. G. 1995. Heavy metal burdens in nine species of freshwater and anadromous fish from the Pechora River, northern Russia. Science of the Total Environment, 160: 653-659.

[12] Mansour, S. A., and Sidky, M. M. 2002. Ecotoxicological studies. 3. Heavy metals contaminating water and fish from Fayoum Governorate, Egypt. Food Chemistry, 78 (1): 15-22.

[13] Barak, N. E., and Mason, C. F. 1990. Mercury, cadmium and lead concentrations in five species of freshwater fish from eastern England. Science of the Total Environment, 92: 257-263.

[14] Papagiannis, I., Kagalou, I., Leonardos Petridis, D., and Kalfakaou, V. 2004. Copper and zinc in four freshwater fish species from Lake Pamvotis (Greece), Environmental International 30: 357-362.

[15] Dick, P. T., and Dixon, D. G. 1985. Changes in circulating blood cell levels of rainbow trout, Salmo gairdneri Richardson, following acute and chronic exposure to copper. Journal of Fish Biology, 26 (4): 475-481.

[16] Dave, G. and Xiu, R. 1991. Toxicity of mercury, copper, nickel, lead, and cobalt to embryos and larvae of zebrafish, Brachydanio rerio. Archives of Environmental Contamination and Toxicology, 21 (1): 126-134.

[17] Mutluay, H., Demirak, A. 1996. Su Kimyası. Beta Basın Yayın Dă̆ıtım, İstanbul, 83-84.

[18] Banks, D., Royset, O., Strant, T., Skarphagen, H. 1995. Radioelement (U, Th, Rn) Concentrations in Norwegian Bedrock Groundwaters, Enviromental Geology, 25: 165-180. 
[19] Şahin, Y. 1999. Çekirdek Fiziğinin Esasları. Çeviri, Atatürk Üniversitesi Yayınları, Erzurum, 1340.

[20] Küçükönder, E. 2009. Kahramanmaraş Yöresinde Doğal Radyoaktivite Tayini, Doktora Tezi, Kahramanmaraş Sütçü İmam Üniversitesi, Fen Bilimleri Enstitüsü, Kahramanmaraş.

[21] Çam, H. 2011. Kahramanmaraş Sır Baraj Göletinde Doğal Radyoaktivitenin Belirlenmesi ve Elemental Analiz. Doktora Tezi, Kahramanmaraş Sütçü İmam Üniversitesi, Fen Bilimleri Enstitüsü, Kahramanmaraş, 1-166.

[22] Korkmaz, H. 2001. Kahraman Maraş Havzası'nın Jeomorfolojisi. İl Kültür Müdürlüğü Yayınları, Kahramanmaraş, No:3, 37-39.

[23] Torpğlu, E. 2006. Aksu Çayı'nda Akarsu Kirliliği, Coğrafi Bilimler Dergisi, Kahramanmaraş, 1103.

[24] Kara, C. 1999. Sır Barajı Gölü'nde Yaşayan Chondrostoma regium (Heckel, 1843) ve Leuciscus cephalus (Linneaus, 1758)'un Bazı Biyolojik Özellikleri, Doktora tezi, Gazi Üniversitesi, Fen Bilimleri Enstitüsü, Ankara.

[25] Kahramanmaraş'ta Aksu Çayı 2018. Aksu Çayı'nda kirlilik http://www.marasmanset.com/guncel/aksu-cayi-tum-kirliligiyle-ulusal-basinda-h22214.html (Erişim Tarihi: 15.02.2021).

[26] Kahramanmaraş’ta yaşam, 2020. Kahramanmaraş'ta Aksu Çayı'nın kirletilmesi. https://www.kahramanmarastv.com/yasam/bir-yandan-korona-bir-yandan-fabrika-atiklarihayatimizi-tehdit-etmeye-h797.html (Erişim Tarihi: 15.02.2021).

[27] Littlemore Scientific Engineering (ELSEC), 1994. 7286 Low Level Alpha Counter User Manual. Railway Lane, Littlemore, Oxford OX4 4PZ, UK.

[28] Ne Technology Limited, 1994a. Instruction Manual for Lead Castle (Type 710C). Bath Road, Beenham, Reading, Berkshire RG7 5PR, England.

[29] Ne Technology Limited, 1994b. Instruction Manual for Windowless Scintillation Counter (Type 6001). Bath Road, Beenham, Reading, Berkshire RG7 5PR, England.

[30] Alkan, H. 1989. İstanbul İçme Suyu Kaynaklarının Kirlilik Analizleri, Radyoaktivite ve Ağır Metal Kirliliği, İstanbul Üniversitesi, İstanbul.

[31] Karahan G. 1997. İstanbul'un Çevresel Doğal Radyoaktivitesinin Tayini ve Doğal Radyasyonların Yııllk Etkin Doz Eşdeğeri. Doktora Tezi, İstanbul Üniversitesi, Fen Bilimleri Enstitüsü, İstanbul.

[32] Doğru, M. And Canbazoğlu, C. 2002. Natural Gross Radioactivity in Various Surface and Tap Waters in Elaziğ, Turkey, Journal of Radioanalytical and Nuclear Chemistry, 254 (2): 379-382.

[33] Doğru, M., Canbazoğlu, C., Şahin, S. 2002. Determination of The Gross Alpha and Beta Radioactivity in Kangal Curative Water, Sivas-Turkey, Balkan Physics Letters, 10 (3): 130-134.

[34] World Health Organization (WHO), 2006. Guideline for Drinking Water Quality.Volume 1: Recommendations,3rd Edition 1st Addendum to vol. 1, Geneva.

[35] Cowart, J.B., Burnett, W.C. 1994. The Distribution of U and Th Decay-Series Radionuclides in the Environment-A Review, J. Environ. Oual., 23: 651-662. 